\title{
MICHAŁ JASKÓLSKI
}

Uniwersytet Jagielloński

\section{Proteuszowy świat myśli politycznej}

Proteusz był — w zależności od wersji mitu — według Roberta Gravesa bogiem, bóstwem bądź królem związanym z żywiołem wodnym, zamieszkującym w morzu u wybrzeży wyspy Faros w otoczeniu stada fok. Posiadał dwie ogromnie ważne umiejętności, a mianowicie zdolność szybkiego przeobrażania się we wszystko, co chciał (wiązano ją też ze zmianą pór roku) oraz wielki dar wieszczenia $^{1}$. Jak wiadomo, profetyzm w mitologii greckiej i codziennym życiu państw i ludzi odgrywał często zasadniczą rolę, stąd i postać Proteusza była znacząca. Jego główną wadą było ogromne lenistwo i niechęć do spełniania wieszczej roli. Dlatego w micie o Aristajosie czy o powrocie Menelaosa spod Troi, ci, którzy potrzebowali jego pomocy lub rady, musieli go schwytać w czasie poobiedniej sjesty i mimo obrony poprzez kolejne przemiany postaci zmusić siłą do spełnienia profetycznych obowiązków. Stąd może rodzić się niejedno pytanie: jakimi są owe idee polityczne, do czego owe idee nas nakłaniają, jak zmieniają nas lub jak my usiłujemy zmieniać je wobec równie zmiennej rzeczywistości? Czy one same są owym Proteuszem, czy też my padamy jego ofiarą lub usiłujemy go nakłonić do spełnienia naszych oczekiwań? Stąd kilka refleksji nader subiektywnych czy nawet osobistych.

Szkic ten powstał z wielu wątpliwości, które od jakiegoś czasu mogą się rodzić, gdy w pracy badawczej i dydaktycznej obcuje się ze światem idei i doktryn politycznych, żyjąc jednocześnie w tzw. realu. Impulsem bezpośrednim było zaproszenie na doroczny Zjazd Katedr Historii Doktryn Polityczno-Prawnych, którego tematem przewodnim ma być „Rewolucjonizm i ewolucjonizm w doktrynach polityczno-prawnych". Nie kwestionuję tu wagi tematu ani szerokiego

${ }^{1}$ R. Graves, Mity greckie, Warszawa 1967. Autor niemal w każdym wypadku podaje wszystkie wersje mitów, z jakimi się zapoznał, toteż rozsiane są one po całości dzieła i należy sięgnąć do indeksu, a w nim do wszystkich odesłań dotyczących danej postaci. 
zakresu pozwalającego potencjalnym autorom na przedstawienie własnych konceptów czy interpretacji wybranych doktryn lub nurtów ideowych. Wątpliwości te powstają raczej na kanwie refleksji, jak dalece pierwiastek pewnej opozycyjności takich pojęć, jak rewolucja-ewolucja dzieli dychotomicznie świat idei.

Śmiem twierdzić, że immanentną cechą tego świata jest właśnie opozycyjność, która jednocześnie bywa siłą uruchamiającą i generującą rodzenie się nowych konceptów politycznych bądź reinterpretacje doktryn z przeszłości. Tym bardziej, że ową opozycyjność można kształtować na różne sposoby i na różnych płaszczyznach — zarówno formalnych, jak np. aktywizm-pasywizm, dynamika-statyka, działanie-zaniechanie, jak i wchodząc w głąb czy raczej w gąszcz aksjologiczny, można budować opozycje takie jak np. tradycyjna już opozycja konserwatyzm-liberalizm, która zrodzi dalsze, takie jak demokracja liberalnarepublikanizm, a potem spór o granice wolności liberalnej i granice wolności republikańskiej, a jeśli wybierzemy np. republikanizm, to zrodzi dysputę na temat, czy wolność należy rozumieć jako brak dominacji (Ph. Pettit, Q. Skinner) czy jako budowanie ideału cnót publicznych i aktywne uczestnictwo w życiu obywatelskim (M. Sandel, M. Viroli)?² Budzić to będzie kolejne opozycje, kontrastując w ramach jednego nurtu ideowego poszczególne jego składniki czy wartości. Nie ukrywam, że w pewnych wypadkach poczytuję to za swoistą grę słowną, którą czasem trudno odnieść do realnego świata toczącej się polityki.

Można też przyjąć z równą pewnością, że owa opozycyjność jest na swój sposób siłą jednoczącą, bo nawet najbardziej skontrastowane poglądy na państwo, prawo czy model uprawiania polityki prowadzą do skupienia uwagi badaczy na funkcjonalnej stronie oddziaływania idei, ergo stymulują pośrednio rozwój dyscypliny badań.

Świadomie wskazałem tu na spór wokół idei republikanizmu, albowiem to on zaowocował - również w literaturze polskiej - polemikami wokół tradycji republikańskich i ich rozumienia, mając podłoże ściśle polityczne (Z. Krasnodębski, R. Legutko, M. Król, W. Bernacki, A. Czarnota, W. Sadurski i wielu innych). Ponadto nie chodzi w tym wypadku o samo eksponowanie różnic w zapatrywaniach polityczno-światopoglądowych, lecz o koncentrację uwagi badaczy (czasem i polityków zarazem) na jednym, za to ważnym ideowo, problemie. Dokonuje się tu równoczesna prezentacja zalet i wad, np. demokracji liberalnej czy demokracji republikańskiej. Adwersarze i adherenci określonego nurtu politycznego ukazują różne oblicza i odmiany doktrynalne, dokonując konfrontacji historycznych i dyskutując bądź o tradycjach republikańskich szlachty, bądź o demokratyzmie tegoż stanu, wracając czasem do jakże starych sporów o przyczyny upadku I RP etc.

${ }^{2}$ Por. D. Pietrzyk-Reeves, Neorepublikańska filozofia publiczna i model demokracji, „Etyka” 48, 2014, s. 120-138. Autorka jest zresztą znawczynią zagadnień republikanizmu — zarówno polskiego, jak i współczesnych dysput na jego temat; por. także jej autorstwa: Ład Rzeczpospolitej. Polska myśl polityczna XVI wieku a klasyczna teoria republikańska, Kraków 2012; Idea społeczeństwa obywatelskiego. Współczesna debata i jej źródła, Torun 2012. 
Dziś „wartości republikańskie” są swoiście traktowane, stanowiąc słowo-znak określonej przynależności ideowej, a zarazem klucz dla usprawiedliwiania zmian wprowadzanych przez władzę. Władzę partii rządzącej, która opowiadając się za republikanizmem, nie wyjaśnia kwestii „wolności od dominacji”, a która — oględnie mówiąc - jest problematyczna, i gdzie w miejsce budowania cnót publicznych i społeczeństwa obywatelskiego wprowadza się ,politykę historyczną" wraz z faktycznym podziałem społeczeństwa, gdzie pojawia się w języku parlamentarnym podział na „panów” i tych, którzy „panami nie są”, gdzie w języku urzędowym i mediach publicznych dokonała się istotna zmiana polegająca na wyparciu terminów „obywatel” czy „obywatelski”, co stanowiło niegdyś swoistą oś językową, przez wszelkie odmiany „narodu” i „polskości”, co znów ma swoje historyczne uzasadnienie w okresach zaborów, powstań, okupacji czy trwania PRL. Ma to swoje głębokie znaczenie, ponieważ w moim przekonaniu „obywatelskość" niesie za sobą wartości jednoczące społeczeństwo wokół państwa, zaś kryterium „narodowości” nabiera dziś charakteru coraz bardziej dzielącego. Istotne jest jednak to, że - w zależności od przekonań autorów biorących udział w sporze - oba te nurty zmieniają swoją postać właśnie jak tytułowy Proteusz. Innymi słowy, pierwiastek opozycyjności tkwiący w ideach politycznych ma swoje co najmniej dwa oblicza, gdyż dzieląc — jednoczy i przeciwstawiając - spaja.

Powyższe przykłady zostały przeze mnie wybrane z rozmysłem, dlatego że zarówno liberalizm, jak i republikanizm nie mają dziś oblicza rewolucyjnego; co najwyżej mogą szybciej lub wolniej ewoluować, pozostając wprawdzie w czasem ostrym sporze, który ma duże znaczenie polityczne, ale trudno tu mówić o wezwaniu do rewolucji. Chyba że przyjmiemy, iż „dobra zmiana” ma cechy rewolucji lub kontrrewolucji. Inaczej oczywiście rzecz się ma z ich przeszłością. Wszak dojrzały liberalizm (dziś klasyczny) był podłożem i zarazem efektem cyklu rewolucji angielskich, lecz Dwa traktaty o rządzie Locke'a wyrosły na gruncie wahań pomiędzy lękami i nadziejami Hobbesa, którego dzieło cieszyło się większym uznaniem parlamentu i stronników Cromwella niż rojalistów. Dalej była to już droga ewolucyjna. Republikanizm francuski miał zdecydowanie rewolucyjny rodowód, albowiem Wielka Rewolucja w sposób oczywisty wywodziła się z podłoża oświeceniowego, którego idei i doktryn nie trzeba omawiać, by wiedzieć, że chodzi o postacie encyklopedystów (głównie D. Diderota, Woltera, Monteskiusza czy wręcz uświęconego przez rewolucję J.J. Rousseau). Tak więc mogą to być przykłady idei, które wewnętrznie doznały zasadniczej przemiany, pod presją czasu i wydarzeń transformujących ich oblicze polityczne i funkcje, jakie miały pierwotnie spełniać. Gdzie zatem leży przyczyna takich procesów? 
Odpowiedź nie może być ani jasna, ani satysfakcjonująca. Wspomniałem na wstępie, że szkic ten powstał pod wpływem prywatnych dylematów związanych z historią doktryn politycznych. Nigdy nie miałem wątpliwości co do konieczności istnienia tej dyscypliny w ramach studiów prawniczych, politologicznych, a dotyczy to w jeszcze większym stopniu filozofii, socjologii czy psychologii, w których wymiar historyczny jest wartością samą w sobie. Wątpliwości te są innej natury i odnoszą się w równej mierze do procesów badawczych, co do dydaktyki. Nie spierając się o definicje takich pojęć, jak idea polityczna, myśl polityczna czy doktryna, pamiętać trzeba jednakże, iż mimo zawsze bliskiego związku z rzeczywistością — wystarczy tu odwołać się do dzieł Platona czy Arystotelesa, gdzie były jej swoistym zwierciadłem i pośrednim dowodem oglądu tejże rzeczywistości — pozostawały niemal wyłącznie tworami myśli autorów. Były jej projekcjami lub wręcz fantazmatami filtrowanymi przez umysł i tam dokonywał się pierwszy niejako etap interpretacji tejże rzeczywistości. Jest to etap tkwiący immanentnie we wnętrzu danej idei czy doktryny, który można określić mianem a u tor s k i e g o. Jego cechą jest jednak bezpośrednie zetknięcie samego autora z otaczającą go rzeczywistością, choćby nawet postrzegał ją w sposób zgoła fałszywy.

Tu pozwolę sobie na mały ekskurs dotyczący pojęcia ,interpretacji”. Otóż używam go w tym wypadku w znaczeniu całkowicie potocznym, mając jednocześnie świadomość istnienia ogromnej literatury i różnych koncepcji interpretacji tzw. humanistycznych szkół filozoficznych, jak: hermeneutyka, strukturalizm, poststrukturalizm czy postmodernizm. Nie ukrywam też, że bliskie są mi koncepcje H.G. Gadamera i jego słowa, że: „Człowiek studiujący dzieje sam określony jest przez doświadczenie dziejów. Historię pisze się wciąż na nowo, bo jesteśmy stale określani przez teraźniejszość”3. Również koncepcja „koła hermeneutycznego" jako koncepcji i zarazem narzędzia metodologicznego nie jest mi do końca obca, mimo niejasności językowych i stylu wypowiedzi samego autora ${ }^{4}$. Wprawdzie wiedzie on niemal wprost do tzw. kontekstualizmu (por. dalsza część szkicu), co może rozszerza, ale i ogranicza możliwości interpretacyjne w historii myśli politycznej, lecz stanowi nader pożyteczną pomoc w zrozumieniu zwłaszcza czasowo odległych idei, pod warunkiem że nie ulega absolutyzacji i nie rości sobie pretensji do wyłączności. Zgadzam się też z licznymi tezami B. Brożka odnośnie do granic interpretacji, a po części z jego modelem interpretacji, choć sądzę, że model ten ma lepsze zastosowanie w naukach prawnych, szczególnie dogma-

${ }^{3}$ H.G. Gadamer, Rozum stowo, dzieje. Szkice wybrane, przeł. M. Łukasiewicz, K. Michalski, Warszawa 1979, s. 44.

${ }^{4}$ H.G. Gadamer, Prawda i metoda. Zarys hermeneutyki filozoficznej, przeł. B. Baran, Warszawa 2007. 
tycznych, niż w przypadku historii doktryn ${ }^{5}$. Sam natomiast żywię wątpliwości związane z semantyką, ponieważ owe projekcje autorów budowane były i są ze słów, których znaczenie podążało za zmienną rzeczywistością, nie wspominając o częstej ich wieloznaczności, co w przełożeniu na politykę zapewne zmieniało często ich pierwotny sens.

Wracając jednak do głównego wątku — wydaje się, że od tego momentu autorskiej interpretacji rzeczywistości zaczyna się oderwanie i wędrówka danej idei czy doktryny po umysłach jej odbiorców, i tu zaczyna się świat zewnętrznego jej istnienia. Tu też rodzi się prawdziwy problem, albowiem jeśli nie mamy dostępu do oryginału lub go po prostu nie znamy (casus Sokratesa), to od tego momentu skazani jesteśmy na interpretacje innych, którzy znów filtrują i przepuszczają przedmiot badawczy przez pryzmat swojej aprobaty bądź uprzedzeń - jest to więc etap interpretacji postautorskiej. Nie miejmy jednak złudzeń co do tego, że poznając oryginał, po pierwsze nie padliśmy już ofiarą np. tłumacza lub komentatora, a po drugie sami nie dokonaliśmy interpretacji we własnej percepcji wedle naszej aprobaty lub potępienia. W związku z tym im bardziej czas i zmiany w rzeczywistości oddalają nas od dzieła i narasta ilość kolejnych interpretacji, tym bardziej oddalamy się od etapu intencji autora.

O ,czasie twórcy” i ,czasie odbiorcy” napisano już wystarczająco dużo (J. Szacki, M. Jaskólski), by drążyć go w dalszym ciągu, jako że istotą sprawy jest raczej fakt, że dana doktryna nie tylko zmienia swoje oblicze, lecz także zmienia się jej funkcja polityczna i społeczna, chyba że w krótkim czasie okazała się martwym płodem myśli lub przeszła w stan hibernacji, mogący trwać nieraz całymi wiekami, po to, by odrodzić się z całkowicie odmienionym obliczem ${ }^{6}$. Jej kontakt z rzeczywistością jest wtedy zupełnie odmienny, a odczytywanie jej w nowym kontekście może oddalać nas o całe eony od etapu autorskiego. Stąd rodzą się nieustające spory pomiędzy tzw. kontekstualistami i prezentystami; spory praktycznie niemożliwe do rozstrzygnięcia w duchu „typu idealnego” interpretacji, co przeradza się w swoisty kompromis czy koegzystencję obu stanowisk, a tytułowy Proteusz święci swoje tryumfy na polu metamorfozy ${ }^{7}$.

Trzeci etap wiąże się już bezpośrednio z naszą własną pracą badawczą i dydaktyczną. Wszak nie ukrywajmy tego, że mamy swoje pola badawcze, które siłą rzeczy znamy lepiej niż inne, na które mamy własny pogląd, i że nie znamy zawsze i do końca obszarów, których nie penetrowaliśmy od strony źródłowej, podpierając się czasem interpretacjami etapu drugiego, zwłaszcza wtedy, gdy są one zgodne z naszymi poglądami. Nie ukrywajmy też, że mamy swoich ulubionych myślicieli czy kierunki, idee, które hołubimy lub które napawają

${ }^{5}$ B. Brożek, Granice interpretacji, Kraków 2014, s. 146-166.

6 J. Szacki, Dylematy historiografii idei oraz szkice i studia, Warszawa 1991, s. 231 n.; M. Jaskólski, Szkice o historii doktryn politycznych i prawnych, „Zeszyty Naukowe Uniwersytetu Jagiellońskiego" DCCXII, Kraków 1985, s. 66-77.

7 Por. J. Szacki, op. cit., s. 15-19. 
nas zwykłą niechęcią, że czasem zmuszeni jesteśmy do pominięcia niektórych fragmentów historii, bo np. liczba godzin dydaktycznych jest zbyt mała, a my z ukrytą radością pomijamy to, co nas mniej nie interesuje. Ćwiczenia, wykład, podręcznik, wybór źródeł wiążą się prawie zawsze z dokonywaniem przez prowadzącego selektywnego i zarazem subiektywnego wyboru. Jeśli miałbym go dość woluntarystycznie określić, to jest to etap interpretacji a rbitraln ej. Tkwi on prawie całkowicie poza etapem autorskim, lecz jest niestety w jakiejś mierze kontynuacją etapu drugiego, wszak zostaje jednak ukształtowany wedle tego, jaką przyjęliśmy metodę, czy to badawczą, czy to dydaktyczną. Sami filtrujemy i transformujemy świat idei politycznych poprzez nasze kompetencje naukowe, lepszy lub gorszy warsztat badawczy, własny język i zdolność do transmisji tego, co pragniemy przekazać słuchaczom.

Można wreszcie pokusić się o próbę odkrycia ostatniej chyba płaszczyzny, którą nawet trudno nazwać, tkwi ona bowiem w pytaniu o efekt dydaktyczny. Innymi słowy i nieco trywialnie pytając: ,co pozostało w głowach słuchaczy?” Czy dokonali oni dalszej, własnej interpretacji, czy wzbudziło to jakiś rezonans natury politycznej, czy zakodowało w ich pamięci jakieś nazwiska lub chociażby fragmenty idei aktualne do dziś, czy potrafili porównać je do otaczającej ich rzeczywistości, czy być może sprowadziło się to w większości do formuły „naucz się i zapomnij"? Bez szerokich badań empirycznych, a takich z pewnością się nie przeprowadzi, pytania te pozostają bez odpowiedzi. System punktacji przedmiotów oraz w większości stosowany egzamin testowy, tudzież rozwój Internetu, skutecznie uśmierciły kontakt bezpośredni. Jest to, w moim przekonaniu, proces nieodwracalny przy obecnym systemie kształcenia na studiach wyższych i w relacji do szeroko widzianej humanistyki, a dotyczy to w równej mierze nie tylko prawa i politologii, lecz — jak wspomniałem - filozofii, socjologii i wszystkich tych dziedzin, które wypracowały dyscypliny historyczne wymagane do pełnego wykształcenia, jeśli rzeczywiście o to władzy chodzi. Nadzieję przynoszą niemal wyłącznie te fora, gdzie kontakt bezpośredni zależy (w przypadku historii doktryn i macierzystego Wydziału Prawa i Administracji Uniwersytetu Jagiellońskiego) od wyboru słuchaczy, czyli ćwiczeń, seminariów licencjackich i magisterskich, a potem często seminariów doktoranckich. Z własnych doświadczeń mogę jedynie stwierdzić, że tu rzeczywiście własna inwencja uczestników, ich innowacyjne podejście do przedmiotu bądź wyboru tematu prac oraz wygłaszanych referatów świadczą, że dokonują oni świadomie własnej interpretacji idei czy doktryn, oczywiście subiektywnie i wedle własnych przekonań politycznych i światopoglądowych. Skala przeobrażeń Proteusza osiąga tu rzeczywiście czasem imponujące wymiary, albowiem rezonowanie niektórych idei w przypadku młodych ludzi bywa czasem zaskakujące i daleko odbiegające od konwencji źródeł, podręczników czy narracji wykładowcy. Osobiście traktuję to jednak jako sukces i nie mogę przysłowiowo rozłożyć rąk i cytując Hobbesa, powiedzieć: Doceo sed frustra. 
Wedle mitów tenże Proteusz miał także zdolność wieszczenia - dziś zapewne powiedzielibyśmy prognozowania, bo jedno i drugie jest równie niejasne i niepewne. Należałoby w tym momencie postawić pytanie o przyszłość, lecz tu natrafiamy na pierwszą barierę w postaci odróżnienia przyczyn od skutków. Oczywiście istnieją prace szeroko dyskutowane, by całkowicie wyrywkowo przypomnieć dzieła S.P. Huntingtona, F. Fukuyamy, Z. Baumana czy H. Kissingera, które w mniejszym lub większym stopniu starają się ukazać rzeczywistość i jej przyszłe następstwa. Jednak mimo ich rozgłosu i wzbudzanych dysput obraz ten wcale nie jest jasny, co więcej — można powiedzieć, że wszyscy uczestnicy tych debat mają poniekąd rację, bo zależy to wyłącznie od perspektywy spojrzenia na zmienną rzeczywistość. Tym bardziej, że prognozy stawiane przez dyskutantów są często nie tylko ze sobą sprzeczne, co przypominają wskazówki dawane przez antyczne wyrocznie. Oczywiście istnieją słowa-klucze, takie jak „globalizacja”, „rewolucja cyfrowa i informatyczna”, ,rewolucja” w naukach przyrodniczych, nakładające się na siebie czy wręcz dążące do jakiejś syntezy, lecz przecież nie jesteśmy w stanie odróżnić w tych kolejnych interferujących falach zmian i rozróżnić, co jest przyczyną, a co skutkiem.

Świat idei politycznych wydaje się tkwić na tym w sumie niewielkim odcinku historii XX i XXI w. - mówiąc językiem F. Braudela — w „czasie zadyszanym" ${ }^{8}$. Zadyszanym, ponieważ więcej zadaje się tu pytań, niż można usłyszeć na nie odpowiedzi, które okażą się poprawnymi. Zadyszanym również dlatego, że brak jest tu czasu na spokojną refleksję, generującą dopiero po chwili namysłu właściwą ocenę sytuacji. Dziś nowe lub odnowione koncepty polityczne powstają i umierają niemal po chwili, gdyż zmiana w rzeczywistości zachodzi szybciej niż refleksja nad nią.

Dotąd, czyli do dziś, byliśmy przyzwyczajeni - lub tak nam się wydawało — do niezbyt szybkiego biegu wydarzeń, a każde przyśpieszenie uważano za dyskomfort w odczuciu zarówno jednostkowym, jak i społecznym. Woleliśmy, by owe wydarzenia miały chwilę, aby rezonować w czasie, lecz w momencie gdy rewolucja cyfrowo-informatyczna oraz nauki przyrodnicze chociażby w zakresie genetyki przestały być „,wynalazkami” i „odkryciami”, a stały się powszechnością i codziennością, konsumowaną w sposób masowy, zmianie uległo niemal wszystko. W tychże „rewolucjach” dostrzegam zresztą główne przyczyny i zarazem główne wektory rozwoju w postaci skutków.

Od tego momentu tempo tworzenia nowych i zarazem przystosowanych do zmiany idei politycznych jak gdyby zwolniło lub wręcz stanęło. Wszelkie

${ }^{8}$ Wydaje się, że jeden z twórców i filarów szkoły Annales trafia tu w sedno problemów dzisiejszej historii doktryn politycznych, pisząc, że: „Historia tradycyjna, wrażliwa na czas krótki, na losy jednostki, na wydarzenia, przyzwyczaiła nas od dawna do swojej spiesznej, dramatycznej, zadyszanej opowieści” (F. Braudel, Historia i trwanie, przeł. B. Geremek, Warszawa 1971, s. 49). 
koncepty w rodzaju libertarianizmu czy komunitaryzmu, mimo że teoretycznie rozwijają się, znajdując zwolenników lub przeciwników, to jednak tkwią korzeniami w przeszłości i przywiązaniu do swoich „katechizmów” aksjologicznych, które być może nie przystają już do świata. Świata, którego różne kręgi cywilizacyjne, kulturowe czy religijne burzą dawny ład, oparty o dorobek myślowy Zachodu, bądź kwestionują go u samych podstaw. Dziś raczej nie do wyobrażenia jest tworzenie kompendiów wiedzy o myśli politycznej, które mogłyby abstrahować od islamu czy konfucjanizmu oraz całego środowiska cywilizacyjnego. W wielu wypadkach w krajach dawniej nazywanych eufemistycznie Trzecim Światem konkurencję z krajami Zachodu wygrywa dziś islam, który mimo spękań wewnętrznych i toczącej się walki wychodzi na zewnątrz z racji swej misyjności z gotowym i zamkniętym systemem, który jest swoistym monolitem złożonym z religii, prawa i doktryny politycznej. Systemem na tyle prostym, by łatwo ukorzeniać się w ubogich i słabo rozwiniętych krajach, za to przeważnie przeludnionych i jednocześnie podatnych na emocjonalizm religijny.

Naturalne jest, że w sytuacji gdy dokonuje się rewolucyjna zmiana rzeczywistości, która przechodzi w Baumanowską „płynną nowoczesność”, musi rodzić się pytanie o skutki ideowe i reakcje tradycyjnego rozumienia państwa i jego władzy oraz stosunku doń obywateli znajdujących się pomiędzy efektami owych „rewolucji”, z którymi przyzwyczaili się już żyć na co dzień, a ramami wytyczanymi nadal przez władzę państwa, w którym żyją też na co dzień ${ }^{9}$. Dochodzi tu do zderzenia lub konfuzji na różnych płaszczyznach, gdzie coraz wyraźniej dostrzega się z jednej strony poszerzanie obszaru wolności jednostkowej poprzez łatwość komunikowania się przez sieć oplatającą cały glob i poszczególne państwa w szczególności, z drugiej zaś możliwość zawężania czy wręcz ograniczania tego obszaru poprzez kontrolę, reglamentację informacji, wreszcie głęboką ingerencję w sferę prywatności obywateli, a w tym wypadku raczej poddanych. W indywidualnych odczuciach może to budzić zupełnie sprzeczne reakcje - z jednej strony poczucie własnej wolności i głoszenia swoich przekonań, z drugiej — lęk przed, jak to określa Bauman, ,postpanoptyzacją” i faktyczną kontrolą oraz stałą inwigilacją naszego życia ${ }^{10}$.

Równie naturalną sprawą staje się konfrontacja tradycyjnie rozumianego państwa i jego władzy z owymi skutkami rewolucyjnymi. W rzeczywistości jest

${ }^{9} \mathrm{~W}$ tym wypadku chodzi szczególnie o wnioski, jakie wyciąga Z. Bauman w pracach: Ptynna nowoczesność, przeł. T. Kunz, Kraków 2006; Z. Bauman, D. Lyon, Płynna inwigilacja. Rozmowy, przeł. T. Kunz, Kraków 2013.

${ }^{10}$ Jest to oczywiste nawiązanie do pomysłu J. Benthama oraz wniosków Z. Baumana i M. Foucaulta (M. Foucault, Nadzorować i karać. Narodziny więzienia, przeł. T. Komendanta, Warszawa 2009). Dylemat ten trafnie określił mój znajomy informatyk, bardzo sceptyczny wobec efektów swojego zawodu, że jest to: „wolność na długość smyczy”, jaką dla nas stanowi na co dzień smartfon połączony z Internetem, co więcej smyczy trwającej nawet po naszej śmierci, bowiem w sieci nic nie ginie. 
to pytanie nie o stopień akceptacji lub odrzucenia owych skutków, lecz o stopień niegodzenia się z nimi. Żadna władza nie może bowiem aprobować wolności obywateli w wymiarze, o którym myślą, marzą lub próbują ją zrealizować, bez możliwości poddania jej kontroli lub reglamentacji. Wolność w danym państwie mierzalna jest w tym wypadku stopniem biernego, lecz stałego przyglądania się przez władzę obywatelowi, badania jego reakcji, emocji, intencji, zamierzeń czy działań lub aktywnej w postaci ingerencji jawnej (np. ograniczenie dostępu do niektórych obszarów sieci) bądź ukrytej (stała kontrola polityczna pod wybranym kątem, np. terroryzmu, lub organizowanie tzw. hejtu wobec wybranego środowiska opozycyjnego). $Z$ drugiej strony stopień przyzwolenia obywateli na takie działania władzy (o których się wie lub nie) lub stopień bierności bądź zaufania do państwa i rządzących określają faktyczne granice wolności, jaką wybierają obywatele, mając w sumie niewielki wpływ na ten wybór z racji możliwości stosowania represji ze strony władzy.

Obraz ten jest może pesymistyczny i zarazem dość tradycyjny w ujmowaniu relacji władza-obywatele, lecz prognozy w tym momencie w niczym nie różniłyby się już od wyroczni. Można w tym wypadku przyjąć założenie, iż:

Władza istnieje dzisiaj w globalnej i eksterytorialnej przestrzeni, ale polityka, która łączyła kiedyś interes jednostki z interesem publicznym, pozostaje lokalna, niezdolna do działania na poziomie globalnym. Bez politycznej kontroli władza staje się źródłem niepewności, ponieważ politycy zachowują często obojętność wobec wielu życiowych problemów i lęków zwykłych ludzi ${ }^{11}$.

Jeśli przyjąć słowa D. Lyona za przynajmniej część prawdy, to rzeczywiście mamy do czynienia z sytuacją, w której „imperium” państwa ogranicza się wyłącznie do sfery wewnętrznej suwerenności, pozostając bezradną np. wobec procesów ekonomicznych, rozgrywających się ponad głowami państw, które mogą być obalone gospodarczo lub znacząco osłabione przez centra decyzyjne o charakterze globalnym i ponadpaństwowym.

Trzeba w tym momencie zadać pytanie, czym może operować ideowo władza państwa znacznie ograniczonego lub wręcz pozbawionego suwerenności zewnętrznej, której pozory będzie zawsze utrzymywać, ale która nadal posiada suwerenność wewnętrzną zamkniętą $\mathrm{w}$ ramach własnej tradycji. Jest to zresztą jedyna sfera dla państwa, które nie jest np. imperium gospodarczym czy militarnym, kiedy to władza nakierowana do wewnątrz może pokazać przysłowiowe „pazury”, choć i tu może spotkać ją porażka w ramach porządku globalnego lub organizacji ponadpaństwowych w postaci represji gospodarczych lub izolacji w układzie międzynarodowym. Przy takim założeniu oblicze ideowe lub oblicze władzy, czy opozycji, przeważnie mieści się w ramach własnych, historycznie zakorzenionych, obyczajów. Tradycja — która wedle wielce trafnej przenośni

11 Z. Bauman, D. Lyon, op. cit., s. 15. 
R. Zimanda to: „łachy i wyspy świadomości w bezrefleksyjnie płynącej rzece dziedzictwa" - stanowi zasadnicze ograniczenie wyboru ideowego ${ }^{12}$.

Tu powracam do zarysowanego na początku szkicu sporu o tradycje demokratyczne i republikańskie. W tym momencie należy przywołać chyba najwybitniejsze dzieło, jakie powstało w Polsce na temat tradycji, w którym J. Szacki pisał:

\begin{abstract}
W społeczeństwach nowoczesnych tradycja jest świadomie kultywowana; powstała ogromna literatura mająca na celu okazanie, dlaczego winniśmy kochać przeszłość albo też jakieś oddzielne jej kawałki. Tradycja jest przedmiotem rozlicznych operacji intelektualnych; wybiera się ją, ocenia, wartościuje, porównuje z innymi, poznaje, propaguje itd. [...] Każde pokolenie dokonuje po swojemu selekcji elementów społecznego dziedzictwa, czyniąc coraz to nowe jego elementy przedmiotem wartościowania, obojętniejąc na inne, zmieniając oceny ujemne na dodatnie i dodatnie na ujemne... Wystarczy stwierdzić, że w społeczeństwach zróżnicowanych nie ma tradycji bez sporu i konfliktu, a w związku z tym bez rozbieżnych interpretacji i ocen tych samych wzorów przeszłości ${ }^{13}$.
\end{abstract}

Oczywiście w przypadku polskiego sporu o tradycję demokratyczną i republikańską dostrzec można owe „operacje intelektualne” po obu stronach areny politycznej. Wszak to właśnie reklamowana przez obóz rządzący ,polityka historyczna” jest ową „operacją", wprawdzie mało intelektualnie wyrafinowaną, lecz w propagowaniu wskazanej do „kochania” tradycji dość skuteczną. Jeśli dokonać rzetelnej weryfikacji historycznej poszczególnych składników wskazywanych tradycji, to ani demontaż państwa prawa, ani kwestionowanie trójpodziału władzy i niszczenie wymiaru sprawiedliwości, ani wreszcie dążenie do centralizacji państwa na każdej płaszczyźnie jego funkcji, a zatem ustanowienie jakiegoś ustroju autorytarnego, nigdy nie leżało $\mathrm{w}$ tradycji republikanizmu polskiego, zwłaszcza I RP, wprost przeciwnie - lęk przed jakąkolwiek formą absolutum dominium towarzyszył jej do momentu ustanowienia Konstytucji 3 maja z wiadomymi potem skutkami politycznymi. Natomiast domieszka nacjonalizmu i populizmu może być co najwyżej wiązana z końcem wieku XIX i podziałami ideowymi II RP, które selektywnie traktowane i łączone z ideą republikańską dają w sumie dość eklektyczny obraz tradycji, do których odwołują się dziś rządzący. Tu też można poznać zdolności Proteusza do przemian jego postaci tudzież wieszczenia przyszłości. Tradycja jednak, nawet ta bardzo selektywnie i dowolnie wybrana pod kątem utrzymania władzy, jest siłą, która nigdy nie jest do końca racjonalna i nigdy nie będzie. Nie ulega ona próbom jakiejkolwiek weryfikacji, w tym historycznej, albowiem przemawia do emocji tej części społeczeństwa, którą legitymuje się aktualna władza, odwołując się do suwerena.

12 R. Zimand, Problem tradycji, [w:] Proces historyczny w literaturze i sztuce. Materiaty konferencji naukowej, maj 1965, red. M. Janion, A. Kmita-Piorunowa, Warszawa 1967, s. 377.

13 J. Szacki, Tradycja, wyd. II rozsz., Warszawa 2011, s. 158, 167-168. 


\section{Bibliografia}

Bauman Z., Płynna nowoczesność, przeł. T. Kunz, Kraków 2006.

Bauman Z., Lyon D., Płynna inwigilacja. Rozmowy, przeł. T. Kunz, Kraków 2013.

Braudel F., Historia i trwanie, przeł. B. Geremek, Warszawa 1971.

Brożek B., Granice interpretacji, Kraków 2014.

Foucault M., Nadzorować i karać. Narodziny więzienia, przeł. T. Komendant, Warszawa 2009.

Gadamer H.G., Prawda i metoda. Zarys hermeneutyki filozoficznej, przeł. B. Baran, Warszawa 2007.

Gadamer H.G., Rozum stowo, dzieje. Szkice wybrane, przeł. M. Łukasiewicz, K. Michalski, Warszawa 1979.

Graves R., Mity greckie, Warszawa 1967.

Jaskólski M., Szkice o historii doktryn politycznych i prawnych, „Zeszyty Naukowe Uniwersytetu Jagiellońskiego" DCCXII, Kraków 1985.

Pietrzyk-Reeves D., Idea społeczeństwa obywatelskiego. Wspótczesna debata i jej źródła, Toruń 2012.

Pietrzyk-Reeves D., Ład Rzeczpospolitej. Polska myśl polityczna XVI wieku a klasyczna teoria republikańska, Kraków 2012.

Pietrzyk-Reeves D., Neorepublikańska filozofia publiczna i model demokracji, „Etyka” 48, 2014.

Szacki J., Dylematy historiografii idei oraz inne szkice i studia, Warszawa 1991.

Szacki J., Tradycja, wyd. II rozsz., Warszawa 2011.

Zimand R., Problem tradycji, [w:] Proces historyczny w literaturze i sztuce. Materiaty konferencji naukowej, maj 1965, red. M. Janion, A. Kmita-Piorunowa, Warszawa 1967.

\section{THE PROTEAN WORLD OF POLITICAL THOUGHT}

\section{Summary}

Referring to the Proteus myth, the author analyses the causes of changes taking place in the image and reception of political ideas and doctrines. He points to the current Polish ideological dispute between the advocates of liberal democracy and concepts of republicanism. Another question concerns the problem of interpretation and its various levels, where metamorphosis usually occurs. Finally, the author points to the problem of choosing tradition as a factor supporting the transformation of ideas and their impact on the current political set-up in Poland.

Keywords: Proteus, myth, liberalism, republicanism, interpretation, tradition.

Michał Jaskólski

michal.jaskolski@uj.edu.pl 